\title{
The Phosphofructokinase of Arthrobacter crystallopoietes
}

\author{
By John Ferdinandus and J. B. Clark \\ Department of Botany and Microbiology, University of Oklahoma, Norman, Okla. 73069, U.S.A.
}

(Received 15 April 1969)

Arthrobacter crystallopoietes is a bacterium that undergoes sphere-rod morphogenesis when grown on a $\mathbf{0 . 5} \%$ glucose-minimal salts medium containing $0.2 \%$ of succinate (Ensign \& Wolfe, 1964). Krulwich \& Ensign (1969) have suggested that glucose is a poor substrate for growth of $A$. crystallopoietes and that enzymes such as PFK* involved in the metabolism of glucose may serve primarily a biosynthetic role rather than play a key role in the regulation of energy metabolism. Under normal environmental conditions it appears that succinate, amino acids and fatty acids provide the main sources of energy for the morphogenesis of Arthrobacter (Krulwich \& Ensign, 1969).

In contrast, $P F K$ enzymes isolated from a number of other plant, animal and bacterial sources have been found to be highly regulated enzymes closely associated with the control of cellular energy metabolism (Uyeda \& Racker, 1965; Walker \& Baily, 1969). An example of such regulation is demonstrated by the response of PFK to adenylate or energy-charge control (Atkinson, 1968; Atkinson \& Walton, 1967) and its response to such allosteric effectors as citrate, phosphoenolpyruvate and $\mathrm{NH}_{4}^{+}$ (Kelly \& Turner, 1968; Underwood \& Newsholme, 1967; Uyeda \& Racker, 1965).

PFK was isolated from $A$. crystallopoietes by $10 \mathrm{~min}$. sonication (Blackstone model SS-2C) in $50 \mathrm{~mm}$-tris-HCl buffer, $\mathrm{pH} \mathrm{8.0}$ at $4^{\circ}$. The disrupted cells were then centrifuged at $20000 \mathrm{~g}$ for $30 \mathrm{~min}$. at $4^{\circ}$. All the following procedures were carried out at $4^{\circ}$. The supernatant was treated with streptomycin sulphate $(0.4 \mathrm{~g} . / \mathrm{ml}$.) to remove nucleic acids and centrifuged at $20000 \mathrm{~g}$ for $20 \mathrm{~min}$. The pellet was discarded and the supernatant was brought to $50 \%$ saturation by addition of $\left(\mathrm{NH}_{4}\right)_{2} \mathrm{SO}_{4}$. The precipitated enzyme was removed by centrifugation at $20000 \mathrm{~g}$ for $20 \mathrm{~min}$. and resuspended in $50 \mathrm{~mm}$ tris-HCl buffer, pH 8.0. The enzyme, purified fivefold, was then dialysed for $12 \mathrm{hr}$. against $50 \mathrm{~mm}$ tris- $\mathrm{HCl}$ buffer, $\mathrm{pH} \mathbf{7 \cdot 5}$.

All assays were performed at $25^{\circ}$ with a Gilford model 2000 recording spectrophotometer by the method of Bauman \& Wright (1968). To detect production of fructose 1,6-diphosphate, excess of aldolase, triose phosphate isomerase, $\alpha$-glycerophosphate dehydrogenase and $\mathrm{NADH}$ were added

*Abbreviation: PFK, phosphofructokinase. to the reaction mixture. PFK activity was proportional to the rate of oxidation of NADH measured spectrophotometrically at $340 \mathrm{~nm}$.

All chemicals employed were obtained through Sigma Chemical Co. (St Louis, Mo., U.S.A.) or Calbiochem (Los Angeles, Calif., U.S.A.), and all coupling enzymes were dialysed for $12 \mathrm{hr}$. against $50 \mathrm{~mm}$-tris- $\mathrm{HCl}$ buffer, $\mathrm{pH} 7 \cdot 5$, to remove $\left(\mathrm{NH}_{4}\right)_{2} \mathrm{SO}_{4}$.

The PFK of $A$. crystallopoietes was found to follow simple Michaelis-Menten kinetics with respect to the substrate, fructose 6-phosphate, and demonstrated no sigmoidal kinetics, a characteristic often associated with regulatory enzymes. The enzyme appeared to lack any kind of adenylate or energy-charge control. Enzyme activity was not inhibited by excess of ATP $(10 \mathrm{mM})$ or affected by ADP, AMP or $3^{\prime}, 5^{\prime}$-(cyclic)-AMP in concentrations up to $10 \mathrm{~mm}$. In addition, enzyme activity was neither inhibited by citrate $(10 \mathrm{~mm})$ or phosphoenolpyruvate $(10 \mathrm{~mm})$, nor activated by $\mathrm{NH}_{4}^{+}(10 \mathrm{~mm})$. Ferdinandus \& Clark (1969) did, however, find the PFK of $A$. crystallopoietes to be selectively inhibited

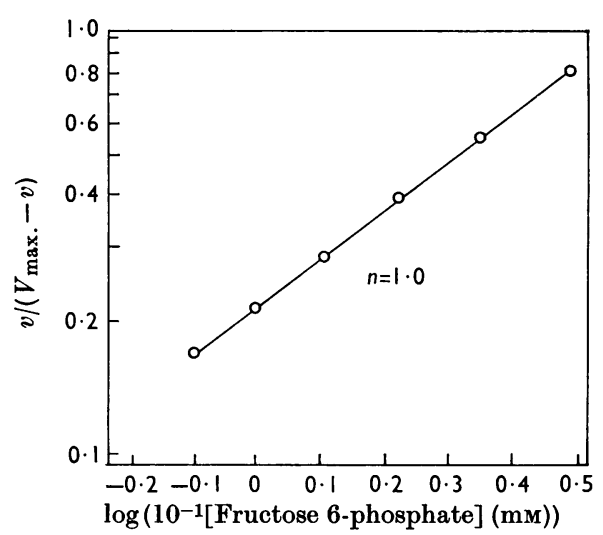

Fig. 1. Hill plot of PFK with respect to substrate fructose 6-phosphate. A slope or interaction coefficient $n=1.0$ was obtained. The reaction mixture contained (final concentrations) $50 \mathrm{~mm}$-tris-HCl buffer, $\mathrm{pH} 8.0,5 \mathrm{~mm}-\mathrm{MgCl}_{2}, 1 \mathrm{~mm}$ dithiothreitol, $0 \cdot 2 \mathrm{~mm}$-NADH, $1 \mathrm{~mm}$-ATP, excess of aldolase, triose phosphate isomerase and $\alpha$-glycerophosphate dehydrogenase, fructose 6-phosphate at the indicated concentrations and enzyme. 
by free fatty acids. From a Hill plot (Atkinson, Hathaway \& Smith, 1965) of PFK activity (Fig. 1) an interaction coefficient $n=1.0$ was obtained, suggesting the lack of interaction between substratebinding sites or lack of homotropic co-operativity (Blangy, Buc \& Monod, 1968).

The PFK of $A$. crystallopoietes is different from PFK isolated from other microbial sources in that the enzyme follows simple Michaelis-Menten kinetics and appears to lack an extensive type of ragulation. Since glucose is not the main source of energy during the morphogenesis of $A$. crystallopoietes, perhaps the PFK of $A$. crystallopoietes has very little to do with the regulation of its own energy metabolism. This could explain the lack of response of PFK to adenylate or energy-charge control, and the lack of response to other effectors such as citrate, phosphoenolpyruvate and $\mathrm{NH}_{4}^{+}$. If energy regulation occurs at sites other than PFK during the morphogenesis, then one might expect a relatively simple type of PFK rather than a highly regulated PFK. This idea is further supported by the fact that Bauman \& Wright (1968) have isolated a PFK from Dictyostelium discoideum that was found to be weakly regulated and followed simple Michaelis-Menten kinetics. A common characteristic of both $A$. crystallopoietes and D. discoideum is that during morphogenesis each organism utilized fats or proteins as an internal energy source rather than exogenous glucose. Thus a highly regulated PFK to help control energy metabolism during morphogenesis may not be needed.

This investigation was supported in part by National Institutes of Health Fellowship no. 1-F1-GM-38945-01 (to J.F.) from the National Institute of General Medical Sciences.

Atkinson, D. E. (1968). Biochemistry, 7, 4030.

Atkinson, D. E., Hathaway, J. A. \& Smith, E. C. (1965). J. biol. Chem. 240, 2682.

Atkinson, D. E. \& Walton, G. M. (1967). J. biol. Chem. 242, 3239.

Bauman, P. \& Wright, B. E. (1968). Biochemistry, 7, 3653. Blangy, D., Buc, H. \& Monod, J. (1968). J. molec. Biol., 81, 13.

Ensign, J. C. \& Wolfe, R. S. (1964). J. Bact. 87, 924.

Ferdinandus, J. \& Clark, J. B. (1969). J. Bact. 98 (in the Press).

Kelly, G. J. \& Turner, J. P. (1968). Biochem. biophys. Res. Commun. 30, 195.

Krulwich, T. A. \& Ensign, J. C. (1969). J. Bact. 97, 526.

Underwood, A. H. \& Newsholme, E. A. (1967). Biochem. J. 104, 296.

Uyeda, K. \& Racker, E. (1965). J. biol. Chem. 240, 4682. Walker, P. R. \& Baily, E. (1969). Biochem. J. 111, 365. 